\title{
Patterns of Investing into Business R\&D in South Africa
}

\author{
Neo Molotja \\ Senior Research Specialist, Centre for Science, Technology and Innovation Indicators (CeSTII), nmolotja@hsrc.ac.za
}

\section{Saahier Parker}

Senior Research Specialist, Research Use and Impact Assessment (RIA), sparker@hsrc.ac.za

\section{Precious Mudavanhu}

Statistician, CeSTII, pmudavanhu@hsrc.ac.za

Human Sciences Research Council (HSRC), 116-118 Buitengracht Street, Cape Town, 8001, South Africa

\begin{abstract}
$\mathrm{T}$ he paper explores the patterns of business investment in research and development $(R \& D)$ using evidence from companies in South Africa in comparison with indicators for a number of other countries. This study covers the period 2006-2016, the studied companies were grouped by the amount of R\&D expenditures (BERD), the number of reports on research performance for the first and last years of monitoring. A typical characteristic of private sector R\&D activities is the uneven distribution of resources in space and time. The major financial and other assets are concentrated within few large companies

from a limited number of industries, while the majority of small and medium-sized enterprises invest in R\&D projects only sporadically, for a period of no more than two consequential years. Firms that perform R\&D for longer periods invest in R\&D incrementally and remain more persistent than enterprises performing less R\&D for shorter time periods. In view of the common nature of a number of several patterns, these observations suggest different approaches to policies supporting R\&D performance in the business sector not only in South Africa, but also in other countries.
\end{abstract}

Keywords: R\&D performance; BERD;

concentration; persistence; volatility; business sector; policy; South Africa
Citation: Molotja N., Parker S., Mudavanhu P. (2019) Patterns of Investing into Business R\&D in South Africa. Foresight and STI Governance, vol. 13, no 3, pp. 51-60. DOI: 10.17323/2500-2597.2019.3.51.60 


\section{Introduction}

$\mathrm{R} \& \mathrm{D}$ performance is increasing worldwide and more so in the developed countries where $\mathrm{R} \& \mathrm{D}$ is driven mostly by the business sector. The increasing dependence on service-orientated sectors across the globe, the rise of knowledge-driven industries, and the emergence of knowledge economies over the preceding decades has radically transformed the way business and economies operate and support growth within countries. The influence of these incrementally transformative shifts in the nature of production has similarly influenced the performance of $R \& D$. These shifts have also influenced $\mathrm{R} \& \mathrm{D}$ policy within these countries to account for the rapid changes over the last few years.

The impacts of these changes have however been unequal and have not been equally transformative within the Global South. This is particularly evident within developing countries, where most R\&D is performed in the public sector and funded by the government. In developed and developing countries however, R\&D performance in the business sector is concentrated in a few industries and at a relatively small number of firms. In addition to concentration as a characteristic of R\&D performance, a significant number of firms are persistent in their performance of $R \& D$ year after year while a larger number exhibit volatility, appearing for one or two years only and spending little on R\&D performance.

Large firms are more likely to be performers of R\&D than the small and medium size enterprises (SMEs). There are several reasons for this: large firms have the financial and human resources to pursue large multiyear R\&D projects, which may take years to yield commercial outcomes. Furthermore, they have the capacity to protect their intellectual property. They possess the infrastructure needed to support the projects and they are able to employ and retain experienced personnel with relevant skills [Antonelli et al., 2013]. This is in contrast with SMEs where many of these conditions are not always possible to meet or initiate.

It has been argued that concentration is a result of smaller firms abandoning their R\&D activities [Rammer, Schubert, 2016]. Rammer and Schubert further argue that their research shows the decline in the number of small $\mathrm{R} \& \mathrm{D}$ performers is not a result of economic downturns. The number of smaller firms performing R\&D continued to decline after the 20082010 economic recession while the larger persistent $R \& D$ performers continued R\&D efforts during and following this period. The point is that persistence and concentration cannot be explained by business cycles, both are a permanent phenomena. However, it also known that business enterprise R\&D (BERD) is affected by economic conditions, that is the availability of funding and aggregate demand [OECD, 2017]. This may further be influenced by the very nature of $R \& D$, as defined in the Frascati Manual [OECD, 2015]. This definition maintains that the nature of R\&D must include a level of uncertainty, novelty as well as systematic approaches toward the creative work undertaken. The uncertainty aspect often limits the scope and willingness to initiate $R \& D$ projects, when the commitment of time, human, and financial investment required to achieve these project goals is considered.

The concentration and persistence of $R \& D$ have value in terms of policy and economic contributions. Pathdependency, the likelihood that a firm will repeat its $\mathrm{R} \& \mathrm{D}$ activities given its past performances, is an example [Máñez et al., 2010]. Management capacity and the performance of $\mathrm{R} \& \mathrm{D}$ increase through learning by doing over time. Learning from R\&D performance may influence the R\&D persistence of firms [Máñez et al., 2010; Rosa, Mohnen, 2013] and their absorptive capacity [Cohen, Levinthal, 2006].

Performing R\&D infrequently leaves the firm in a far less capable state to resume R\&D operations at a later stage. This is a result of the technologies and facilities for R\&D becoming obsolete, together with the loss of human resources required to perform $\mathrm{R} \& \mathrm{D}$.

A decision not to perform R\&D is not easy to reverse, the firm loses its skills and capabilities to undertake $\mathrm{R} \& \mathrm{D}$, and market opportunities erode with time [Rammer, Schubert, 2016]. Máñez et al. [Máñez et al., 2009] support these arguments that sunk costs make it difficult for firms to re-enter and exit the R\&D landscape [Máñez et al., 2009]. Nevertheless, there is still significant volatility where there is a large number of one-off $\mathrm{R} \& \mathrm{D}$ performers and those that abandon their $R \& D$ activities after a few years. The reasons may differ from country to country, but the phenomenon is common and may have an impact upon system-wide R\&D investment.

This paper draws on the trends of R\&D performance of South African firms in the ten-year period of $2006 / 2007$ to $2015 / 2016$. The concentration of R\&D performance, persistence in the performance of $R \& D$, volatility of R\&D performers, and dominant industries are examined. This approach follows similar work performed elsewhere [Schellings, Gault, 2002; Rammer, Schubert, 2016]. Based on the empirical evidence, policies for promoting R\&D in South Africa are considered. While the paper deals with South African firms, the findings and recommendations may be broadly applicable across the continent and the developing world.

\section{Methodology}

The national R\&D survey team at the Human Sciences Research Council (HSRC) has developed its in-house database of R\&D performers among firms in South Africa over the past 18 years.

This paper uses business sector R\&D expenditure data collected in the ten-year period between 2006/2007 and $2015 / 2016$. The firms were divided into six R\&D expenditure groups, which are based on the amount of money spent on R\&D performance in South Africa. The R\&D expenditure groups were created based on either the last year of the appearance of the firm in 
Table 1. R\&D Expenditure Groups

\begin{tabular}{|l|l|}
\hline \multicolumn{1}{|c|}{ Expenditure Group } & \multicolumn{1}{c|}{ ZAR } \\
\hline Massive R\&D & 40 million or more \\
\hline Large R\&D & 20 million - 39 999 999 \\
\hline Medium Upper R\&D & 10 million - 19999999 \\
\hline Medium Lower R\&D & $5000000-9999999$ \\
\hline Small Upper R\&D & $1000000-4999999$ \\
\hline Small Lower R\&D & less than 1 000000 \\
\hline $\begin{array}{l}\text { Note: all R\&D expenditure in this paper is in current Rands (ZAR). } \\
\text { Source: authors. }\end{array}$ \\
\hline
\end{tabular}

the survey or the first year of its appearance (Table 1). Firms were also classified according to the number of times they reported $R \& D$ performance in the ten-year period being studied.

\section{Findings}

The business sector is the largest performer of $\mathrm{R} \& \mathrm{D}$ in South Africa. Despite its dominance regarding gross domestic expenditure on R\&D (GERD), business expenditure on $\mathrm{R} \& \mathrm{D}$ (BERD) declined in nominal terms between 2008/2009 and 2010/2011 and began picking up from 2011/2012 (Figure 1). On the contrary, the ratio of BERD to GERD has been declining since $2009 / 2010$ to below $50.0 \%$ and it looks set to approach the $40 \%$ mark unless there is an upswing of BERD in the following survey periods. The reasons are many, but the one that stands out for this series is the decline in BERD due to the impact of a policy decision during this period. Other $R \& D$ performers that ceased $R \& D$ over the same period may have exacerbated the decline.
This trend however, is not unique to the South African R\&D system nor to developing countries. When reviewing BERD/GERD data from the OECD Main Science and Technology Indicators (MSTI) (OECD, 2019), it emerged that a large number of countries exhibit a similar decline in BERD/GERD ratios across the recent reference period. Figure 2 shows that Mexico, Argentina, Greece, and Portugal ${ }^{1}$ have recorded general decreases in the BERD/GERD ratio within the ten-year reference period (2006-2015), in which most had a BERD/GERD ratio below 50\%. Declining BERD/ GERD ratios are key indicators pointing to possible changes in domestic R\&D systems. These changes may be related to turbulent economic conditions, declining private investment, changes to the political and policy environment, and minimal Foreign Direct Investment (FDI).

The analysis of the results begins with a review of the distribution of firms, according to expenditure group, in each of the ten years examined in this paper.

Metadata from the National R\&D survey series provides information on the total number of firms returning survey questionnaires (containing R\&D information) each year across the ten-year reference period (Table 2). The R\&D survey on average covers approximately 500 firms, despite larger numbers being requested to participate annually. The impact of the 2008 financial crisis on the number of South African $\mathrm{R} \& \mathrm{D}$ performing firms can be observed within the data in Table 2, however, it appears from 2014/2015 that the number of $\mathrm{R} \& \mathrm{D}$ performing firms are increasing.

The business enterprise sector in South Africa consists of large and small R\&D performing firms. The firms represented in the South African survey are not representative of all domestic businesses, but a purposive sample of R\&D performing firms within the domestic

\section{Figure 1. South African BERD and the BERD/GERD Ratio (2006-2016)}

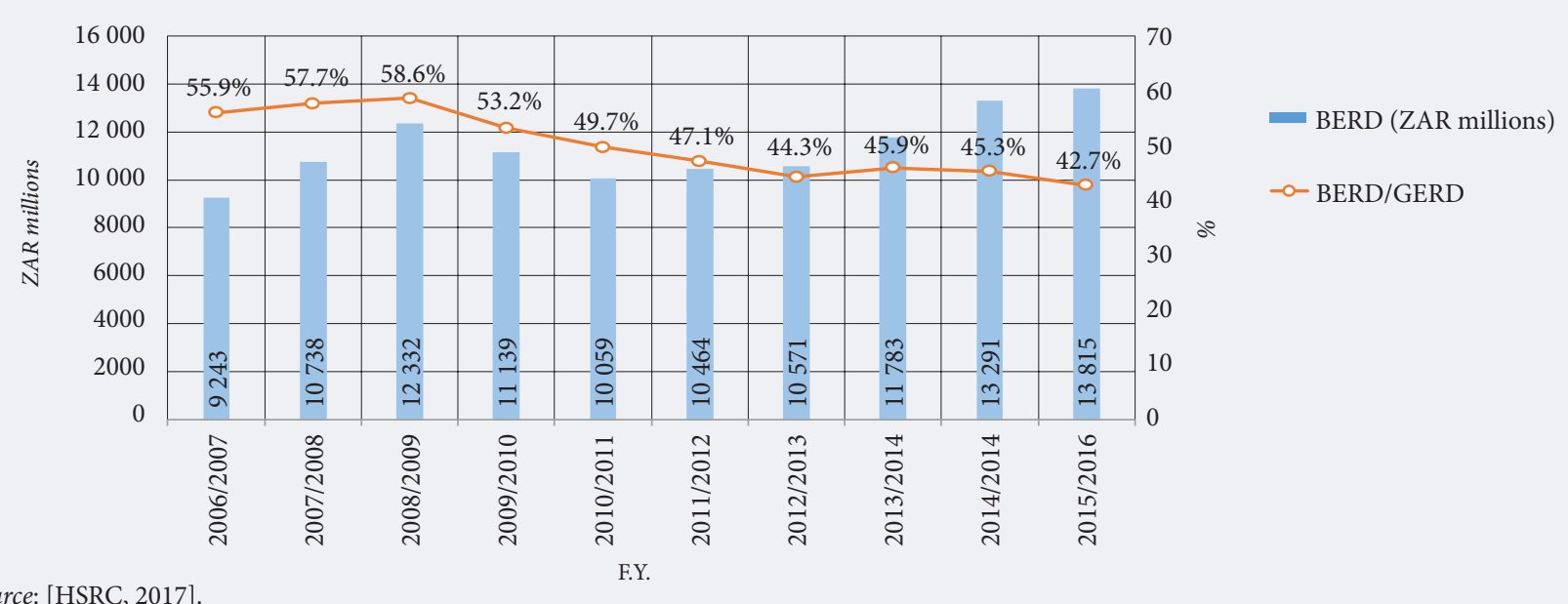

Source: [HSRC, 2017]

\footnotetext{
The BERD/GERD ratio for Portugal has since increased to 50.5\% in 2017 [OECD, 2019].
} 
Table 2. Number of Firms Present in Annual South African R\&D Surveys by R\&D Expenditure Groups (2006/2007 - 2015/2016)

\begin{tabular}{|l|c|c|c|c|c|c|c|c|c|c|c|}
\hline $\begin{array}{l}\text { Expenditures } \\
\text { ZAR millions) }\end{array}$ & $\begin{array}{c}\mathbf{2 0 0 6 /} \\
\mathbf{2 0 0 7}\end{array}$ & $\begin{array}{c}\mathbf{2 0 0 7 /} \\
\mathbf{2 0 0 8}\end{array}$ & $\begin{array}{c}\mathbf{2 0 0 8 /} \\
\mathbf{2 0 0 9}\end{array}$ & $\begin{array}{c}\mathbf{2 0 0 9 /} \\
\mathbf{2 0 1 0}\end{array}$ & $\begin{array}{c}\mathbf{2 0 1 0 /} \\
\mathbf{2 0 1 1}\end{array}$ & $\begin{array}{c}\mathbf{2 0 1 1 /} \\
\mathbf{2 0 1 2}\end{array}$ & $\begin{array}{c}\mathbf{2 0 1 2 /} \\
\mathbf{2 0 1 3}\end{array}$ & $\begin{array}{c}\mathbf{2 0 1 3 /} \\
\mathbf{2 0 1 4}\end{array}$ & $\begin{array}{c}\mathbf{2 0 1 4 /} \\
\mathbf{2 0 1 5}\end{array}$ & $\begin{array}{c}\mathbf{2 0 1 5 /} \\
\mathbf{2 0 1 6}\end{array}$ & Total \\
\hline More than 40 & 53 & 59 & 59 & 58 & 54 & 53 & 53 & 55 & 61 & 60 & 565 \\
\hline $20-40$ & 51 & 51 & 51 & 59 & 47 & 50 & 37 & 38 & 36 & 34 & 454 \\
\hline $10-20$ & 49 & 59 & 65 & 53 & 47 & 47 & 46 & 52 & 52 & 52 & 522 \\
\hline $5-10$ & 63 & 59 & 64 & 60 & 57 & 48 & 58 & 50 & 58 & 54 & 571 \\
\hline $1-5$ & 248 & 262 & 282 & 255 & 106 & 114 & 127 & 115 & 152 & 133 & 1794 \\
\hline Less than 1 & 213 & 233 & 241 & 162 & 64 & 68 & 81 & 68 & 78 & 132 & 1340 \\
\hline Total & 677 & 723 & 762 & 647 & 375 & 380 & 402 & 378 & 437 & 465 & \\
\hline
\end{tabular}

Source: [HSRC, 2017].

private sector. This sample consists of R\&D performing units whose investment in $\mathrm{R} \& \mathrm{D}$ activities covers a broad range of expenditure values. The segments within these investment profiles have been further disaggregated to best reflect the size and nature of R\&D investment across the private sector (see Table 1 above). Understanding the profiles of R\&D performing firms within the South African economy relates not only to the relative size of annual $\mathrm{R} \& \mathrm{D}$ investments but also to the regularity of this investment across a given time period. This relates to the concept of persistence of $\mathrm{R} \& \mathrm{D}$ investment, which is the individual enterprises' continued annual investment in R\&D activity as reflected within subsequent R\&D survey measures. At the opposite end of this spectrum, is the notion of volatility where firms appear less frequently in annual R\&D statistics as a result of less persistent investments or investment strategies as they relate to internal R\&D programs [Rumbelow, Blankley, 2012]. Understanding $\mathrm{R} \& \mathrm{D}$ persistence and volatility allows researchers and

\section{Figure 2. BERD/GERD Ratio, South Africa} and Selected Countries (2006-2015)

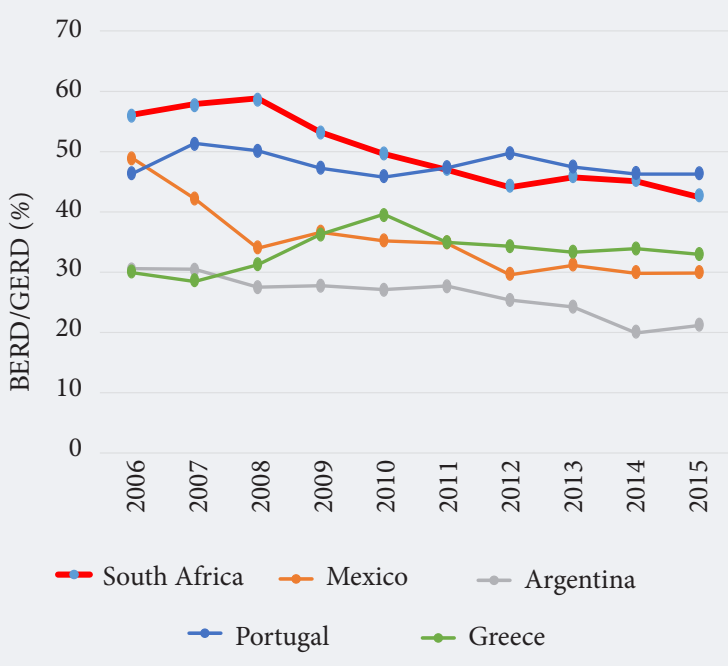

Sources: [OECD, 2019; HSRC, 2017]. policy makers to devise instruments that will support various actors in any $\mathrm{R} \& \mathrm{D}$ system that will move one toward adopting strategies that advance a strategic advantage that propel knowledge generation, and ensure adequate knowledge transfer and human capital development. Kang et al. (2017) argue that acquiring knowledge consistently through $\mathrm{R} \& \mathrm{D}$ investment across a longer period is more efficient than investing a similar total value in half of the original time period [Kang et al., 2017].

Between the concepts of R\&D persistence and volatility rests a similar concept of R\&D concentration. This relates to a large amount of $\mathrm{R} \& \mathrm{D}$ performance emanating from a relatively small number of $\mathrm{R} \& \mathrm{D}$ performing firms. While there will always be some level of R\&D concentration in an economy, at a general level or within particular industrial sectors, the concentration of $R \& D$ indicates a large amount of $R \& D$ expenditure originating from a small number of firms.

$\mathrm{R} \& \mathrm{D}$ performing firms were classified using the groupings indicated, based on their annual R\&D investment profile. As expected, firms investing larger annual R\&D budgets contributed significantly more to total BERD, when compared to firms committing to smaller BERD investments. When reviewing the South African data, it is clear that the number of firms investing larger amounts in the performance of R\&D represent a smaller portion of the total number of firms surveyed. Figure 3 above demonstrates this finding, wherein $61.0 \%$ of total BERD in South Africa across a ten-year period, was invested by only $5.0 \%$ of companies that performed $\mathrm{R} \& \mathrm{D}$ within this period.

At the opposite end of Figure 3, it remains clear that the largest number of firms $(71.0 \%$ in the two smallest classes) contribute a significantly smaller share to total $\mathrm{R} \& \mathrm{D}$ performance ( $8.0 \%$ of funding spent).

This pattern is indicative of highly concentrated of R\&D in South Africa and may highlight the need for strategic policies to best address the relative persistence, volatility, and concentration of R\&D activity.

Alternatively, the concentration phenomenon can be assessed using the number of firms as illustrated 
Table 3. BERD Concentration by the Largest R\&D Performing Units

\begin{tabular}{|c|c|c|c|c|c|c|c|c|c|c|}
\hline Reporting period & $\begin{array}{l}2006 / \\
2007\end{array}$ & $\begin{array}{l}2007 / \\
2008\end{array}$ & $\begin{array}{c}2008 / \\
2009\end{array}$ & $\begin{array}{l}2009 / \\
2010\end{array}$ & $\begin{array}{l}2010 / \\
2011\end{array}$ & $\begin{array}{l}2011 / \\
2012\end{array}$ & $\begin{array}{l}2012 / \\
2013\end{array}$ & $\begin{array}{l}2013 / \\
2014\end{array}$ & $\begin{array}{l}2014 / \\
2015\end{array}$ & $\begin{array}{l}2015 / \\
2016\end{array}$ \\
\hline Number of observations & 677 & 723 & 762 & 647 & 375 & 380 & 398 & 374 & 437 & 403 \\
\hline BERD (ZAR millions) & 9243.2 & 10738.5 & 12332 & 11139.2 & 10059.0 & 10464.0 & 10570.7 & 11782.8 & 13291.0 & 13815.0 \\
\hline Top 300 (\%) & 95.9 & 95.7 & 95.7 & 96.1 & 99.5 & 99.5 & 99.4 & 99.6 & 99.0 & 99.4 \\
\hline Top 200 (\%) & 91.7 & 91.6 & 91.9 & 92.0 & 96.7 & 96.9 & 96.8 & 97.3 & 96.5 & 97.2 \\
\hline Top $100(\%)$ & 79.2 & 79.3 & 80.8 & 79.5 & 85.9 & 86.4 & 87.7 & 88.9 & 88.6 & 89.8 \\
\hline Top $75(\%)$ & 72.7 & 73.4 & 75.7 & 73.5 & 79.9 & 80.4 & 82.6 & 84.0 & 83.9 & 85.6 \\
\hline Top $50(\%)$ & 63.8 & 64.8 & 68.0 & 64.8 & 71.3 & 71.9 & 74.3 & 76.2 & 76.5 & 78.6 \\
\hline Top $25(\%)$ & 48.4 & 50.3 & 55.5 & 50.0 & 53.9 & 55.9 & 59.7 & 62.3 & 63.0 & 64.8 \\
\hline Top $10(\%)$ & 32.7 & 35.1 & 42.0 & 33.5 & 35.7 & 37.0 & 43.3 & 45.1 & 46.7 & 47.4 \\
\hline
\end{tabular}

in Table 3. From 2013/2014 to 2015/2016, the top 10 firms made up almost half of BERD. In 2014/2015 and 2015/2016, the top 100 firms contributed $88.6 \%$ and $88.9 \%$ of BERD, respectively, while the remaining $\sim 10 \%$ of BERD per each year was from the rest of the firms, consisting of about 337 firms.

In this regard, it may be difficult to make confident conclusions about the composition of the rest of firms ("the tail"). Although there is no evidence of causality, one can assume though that the rest of the tail is a combination of firms with small R\&D expenditures as well as the contribution of small firms that naturally spend less on R\&D. The former and the latter may just as well be the firms that quit after one or two years. Similarly, they may well be persistent but contributing little to BERD every survey cycle (see Table 2 , number of firms spending less than ZAR 1 million over the tenyear period).

The phenomenon described above is not unique to South Africa. For instance, the OECD STI Scoreboard

\section{Figure 3. Distribution of R\&D in South Africa by Groups of Companies(\%)}

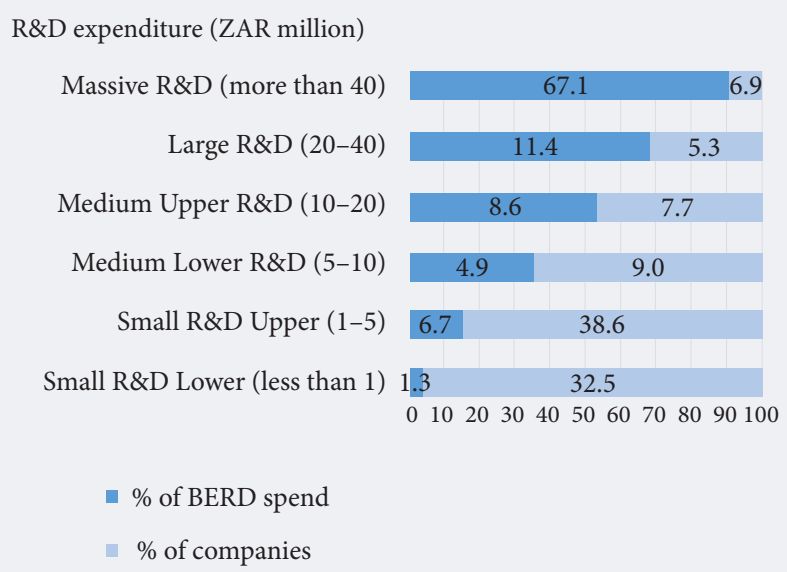

$\begin{array}{rllllllllll}0 & 10 & 20 & 30 & 40 & 50 & 60 & 70 & 80 & 90 & 100\end{array}$

Source: [HSRC, 2017].
2017 indicated that the 50 largest domestic R\&D performers account for $40 \%$ of BERD in Canada and the United States, 55\% in Germany and Japan, and 70\% in Denmark and New Zealand. However, the interpretation of the results should take account of the size of the country and number of business R\&D performers [OECD, 2017].

South Africa's R\&D investment is not only concentrated within a group of large firms; it is also concentrated within particular sectors of the economy. Among the largest business R\&D performers (> ZAR 40 million), $73.6 \%$ of total expenditure on R\&D performance was performed within the financial intermediation, real estate, business services, and manufacturing sectors (Figure 4).

The remaining sectors within this group of $R \& D$ actors include the mining and quarrying, electricity, gas, and water supply, and community, social, and personal services sectors. As already discussed, this group of massive R\&D performers accounts for $61.0 \%$ of total

\section{Figure 4. Concentration of R\&D Activity in the South African Private Sector (\%)}

Financial Intermediation, Real Estate and Busianess Services 39.0 Manufacturing 34.6 Mining and Quarrying 7.6 Electricity, Gas and Water Supply 6.3

Community, Social and Personal Services 4.3 


\section{Table 4. State-Owned Firms' R\&D Investment - Profile}

\begin{tabular}{|l|l|c|}
\hline \multicolumn{1}{|c|}{ Group } & \multicolumn{1}{|c|}{$\begin{array}{c}\text { Average R\&D } \\
\text { Spendings, ZAR }\end{array}$} & $\begin{array}{c}\text { Year } \\
\text { Count }\end{array}$ \\
\hline Electricity, Gas and Water Supply & 812966410 & 9 \\
\hline $\begin{array}{l}\text { Transport, Storage and } \\
\text { Communication }\end{array}$ & 421702588 & 8 \\
\hline Manufacturing & 322429639 & 7 \\
\hline $\begin{array}{l}\text { Agriculture, Hunting, Forestry } \\
\text { and Fishing }\end{array}$ & 13817443 & 4 \\
\hline Source: [HSRC, 2017]. & \\
\hline
\end{tabular}

business R\&D within this period. The five sectors in cluded in the above figure account for $92.0 \%$ of these segments' total R\&D investment, indicating a highly concentrated focus around the services and manufacturing sectors. This trend is similarly visible in other industrialized economies around the world including the US, the UK, Germany, and multiple others.

The concentration of $R \& D$ is further visible through government support and expenditure on the R\&D activities of the public business firms, the state-owned enterprises (SOEs). The SOEs are classified and measured along with private sector enterprises in the R\&D survey. These firms contribute significantly to numerous classifications of $\mathrm{R} \& \mathrm{D}$ performers, however, in the cohort of massive R\&D performers they appear to be highly persistent within this reference period (2006/2007 - 2016/2017). This investment in R\&D on an annual basis is aligned with the mandate of SOEs in South Africa, which is geared toward achieving various socioeconomic goals set by government.

Within the reference period, 13 of these SOEs have been present in the R\&D survey for four or more years (Table 4). The majority of these SOEs are within the massive R\&D performer cohort and had been present in the South African National R\&D survey for seven or more years investing an average of ZAR 400 million annually.
How Concentration, Persistence, and Volatility Manifest Themselves in the South African R\&D Surveys

The review of the R\&D performers within the stipulated ten-year period shows that $1,437 \mathrm{R} \& \mathrm{D}$ performers participated in the survey and provided information on national R\&D statistics. The data shows that the largest portion of firms investing in R\&D activity do so for shorter, rather than longer periods.

Table 5 shows the presence of two expenditure categories where the year 1 population (537) exceeds that in year $10(144)$. Of the 1,437 firms in the survey, 537 (37.4\%) firms were present for just one year while just under $50 \%$ of all firms surveyed within a ten-year period engage in $R \& D$ activity for two years or less. Conversely, only $10.0 \%$ of the total sample were continuously performing $\mathrm{R} \& \mathrm{D}$ for 10 years, accounting for only 144 of the 1,437 companies surveyed within this period. Fewer firms were persistently active beyond four consecutive years. This may be because of private $R \& D$ funding or $R \& D$ project-specific time scales. Furthermore, this may be indicative of a defined timescale for public funds to be invested in R\&D at SOEs and funding of private R\&D by the South African government. Among these 1,437 firms, the largest number of firms invested less than ZAR 5 million in R\&D activities (1,055 or $73.4 \%$ ), while very few firms ( 93 or $6.5 \%$ ) invested ZAR 40 million or more in R\&D activity during the ten-year period.

Table 6 presents total BERD in the most recent year of firms' appearance in the survey. These data paint a different picture when looked simultaneously with data presented in Table 5, which is related to the proportional representation of $\mathrm{R} \& \mathrm{D}$ performing firms across the reference period. Notwithstanding the larger numbers of firms represented in the smaller R\&D investment value groups (Table 6), the largest $\mathrm{R} \& \mathrm{D}$ investment value was derived from among the smaller group of enterprises, investing ZAR 40 million or more annually in $\mathrm{R} \& \mathrm{D}$ across the ten-year period. This analysis confirms that the 39 firms represented in the ZAR 40 million+ group, which had persistently invested in $R \& D$ for 10 or more years, account for $40.6 \%$ of total R\&D expenditure across the ten-year period. Counter to

Table 5. Number of Firms by Years Invested in R\&D and BERD Values

\begin{tabular}{|c|c|c|c|c|c|c|c|c|c|c|c|}
\hline \multirow{2}{*}{$\begin{array}{l}\text { Expenditure group } \\
(Z A R \text { millions })\end{array}$} & \multicolumn{10}{|c|}{ Years of R\&D survey coverage } & \multirow{2}{*}{ Total } \\
\hline & 1 & 2 & 3 & 4 & 5 & 6 & 7 & 8 & 9 & 10 & \\
\hline More than 40 & 6 & 7 & 11 & 9 & 1 & 4 & 6 & 5 & 5 & 39 & 93 \\
\hline $20-40$ & 9 & 6 & 4 & 12 & 6 & 4 & 3 & 5 & 5 & 22 & 75 \\
\hline $10-20$ & 19 & 13 & 9 & 8 & 10 & 6 & 4 & 5 & 5 & 27 & 106 \\
\hline $5-10$ & 19 & 17 & 9 & 19 & 5 & 2 & 5 & 4 & 6 & 22 & 108 \\
\hline $1-5$ & 192 & 72 & 46 & 105 & 27 & 15 & 25 & 13 & 11 & 22 & 528 \\
\hline Less than 1 & 292 & 45 & 41 & 74 & 18 & 17 & 11 & 8 & 9 & 12 & 527 \\
\hline \multirow{2}{*}{ Total } & 537 & 160 & 120 & 227 & 67 & 48 & 54 & 40 & 40 & 144 & \multirow{2}{*}{1437} \\
\hline & $37.4 \%$ & $11.1 \%$ & $8.4 \%$ & $15.8 \%$ & $4.7 \%$ & $3.3 \%$ & $3.8 \%$ & $2.8 \%$ & $2.8 \%$ & $10.0 \%$ & \\
\hline
\end{tabular}


Table 6. ZAR Value of Firms' R\&D Investment by Years Invested and BERD Value Group

\begin{tabular}{|c|c|c|c|c|c|c|c|c|c|c|c|}
\hline \multirow{2}{*}{$\begin{array}{c}\text { Expenditure group } \\
(Z A R \text { millions })\end{array}$} & \multicolumn{10}{|c|}{ Years of R\&D survey coverage } & \multirow{2}{*}{ Total } \\
\hline & 1 & 2 & 3 & 4 & 5 & 6 & 7 & 8 & 9 & 10 & \\
\hline More than 40 & $4.1 \%$ & $2.7 \%$ & $4.7 \%$ & $3.5 \%$ & $0.5 \%$ & $1.6 \%$ & $2.6 \%$ & $5.6 \%$ & $3.8 \%$ & $40.6 \%$ & 13799.36 \\
\hline $20-40$ & $1.3 \%$ & $0.9 \%$ & $0.6 \%$ & $1.8 \%$ & $0.8 \%$ & $0.6 \%$ & $0.4 \%$ & $0.8 \%$ & $0.6 \%$ & $3.3 \%$ & 2193.63 \\
\hline $10-20$ & $1.4 \%$ & $1.0 \%$ & $0.7 \%$ & $0.6 \%$ & $0.8 \%$ & $0.4 \%$ & $0.3 \%$ & $0.4 \%$ & $0.3 \%$ & $2.0 \%$ & 1545.68 \\
\hline $5-10$ & $0.7 \%$ & $0.6 \%$ & $0.3 \%$ & $0.7 \%$ & $0.2 \%$ & $0.1 \%$ & $0.2 \%$ & $0.1 \%$ & $0.2 \%$ & $0.8 \%$ & 769.50 \\
\hline $1-5$ & $2.0 \%$ & $0.9 \%$ & $0.5 \%$ & $1.3 \%$ & $0.3 \%$ & $0.2 \%$ & $0.4 \%$ & $0.2 \%$ & $0.2 \%$ & $0.3 \%$ & 1241.39 \\
\hline Less than 1 & $0.5 \%$ & $0.1 \%$ & $0.1 \%$ & $0.2 \%$ & $0.0 \%$ & $0.0 \%$ & $0.0 \%$ & $0.0 \%$ & $0.0 \%$ & $0.0 \%$ & 226.31 \\
\hline \multirow{2}{*}{ Total } & $10.0 \%$ & $6.2 \%$ & $6.9 \%$ & $8.1 \%$ & $2.6 \%$ & $2.9 \%$ & $3.9 \%$ & $7.2 \%$ & $5.1 \%$ & $47.0 \%$ & $100.0 \%$ \\
\hline & 1984.47 & 1229.32 & 1367.23 & 1601.37 & 526.38 & 580.92 & 786.16 & 1428.02 & 1017.48 & 9309.54 & 19775.88 \\
\hline
\end{tabular}

the representativeness of enterprises in Table 5, firms present in the R\&D survey for fewer than two years at any level of investment value only account for $16.0 \%$ of total R\&D investment (Table 6).

The findings in Tables 5 and 6 are similar to those found in a Canadian study where there is a large number of firms with less than $\$ 100,000$ (top spending in Canada was $\$ 10$ million or more) and present for only one year [Schellings, Gault, 2002]. The pattern of concentration, persistence, and volatility is similar in these countries despite the differences in the structure of the firms. ${ }^{2}$

The findings raise questions about why some firms spend little on R\&D performance and why they do not continue to perform R\&D beyond two years. The relatively larger number of smaller R\&D performers can contribute significantly to increasing the stock of knowledge as well as encouraging specialization within the specific sectors. These firms may further contribute to knowledge transfer, human capital development and economic growth within their industries. All these activities have an impact upon social development and policy-specific considerations that may be considered toward best supporting small, micro, and medium sized enterprises (SMMEs) and start-up companies investing in smaller R\&D projects [Berry et al., 2002].

Another observation that adds to the questions raised in the previous paragraph is from comparing the annual average salary of an engineer or scientist in the private sector to the BERD of the firm employing them. The average salary for an engineer in South Africa is about ZAR 500,000 [Average Salary Survey, 2019]. This amount may be equal to or less than the R\&D expenditures of firms in the lower spending category.

Given this scenario, there is the possibility that there are employees earning more than the BERD of the firm which employs them. This further adds to the questions raised above as to are why these firms performing such $R \& D$ in the first place. What are the implications and the costs thereof? This makes sense if the R\&D performed in-house is being purchased by others (outsourced by other firms). However, this does not fully explain how the R\&D performing firm maintains its $\mathrm{R} \& \mathrm{D}$ competencies over the years.

At the opposite end of this spectrum, it is evident that despite the smaller number of firms investing ZAR 40 million or more (annually) in R\&D, this group of firms contributes a larger share of total BERD. This concentration of larger R\&D investment from a smaller group of R\&D performing business enterprises further points to the significant concentration of $R \& D$ performance, annually and across the ten-year reference period of this study. Despite being a smaller group of firms in the private sector, these companies, their associated projects, staff, potential outputs, and products are often highly visible and may attract increased media coverage and form the basis of corporate expansion and growth strategies

Over and above the benefits accrued by the individual firm, these larger $\mathrm{R} \& \mathrm{D}$ projects and their outputs further promote South Africa as a research destination, attracting critical S\&T workers, foreign direct investment, and collaborative opportunities into the domestic R\&D system. The questions to ask in this instance are what drives $R \& D$ at a relatively small number of firms and what are the potential spill-overs to stimulate $\mathrm{R} \& \mathrm{D}$ at other firms and in other sectors of the economy?

The results so far indicate that presence of a higher degree of concentration, in terms of both firm numbers and the value of R\&D investment. Turning one's attention to the notion of persistence of $R \& D$ investment, a similar yet somewhat different picture of the South African business sector emerges. The term persistence often goes with the concept of volatility in R\&D investment. While persistence refers to the propensity of an enterprise to continue its $\mathrm{R} \& \mathrm{D}$ activity year-on-year,

\footnotetext{
It is also interesting to observe that there has been the Scientific Research and Experimental Development (SR\&ED) tax credit program in place for decades along with other support programs available through the Industrial Research Assistance Program (IRAP) [Government of Canada, 2019; NRC, 2019]. South Africa has a R\&D Tax Incentive program, Support Program for Industrial Innovation (SPII), Technology and Human Resources for Industry Program (THRIP), and other instruments designed to boost R\&D and innovation across the South African firms.
} 
volatility refers to the opposite practice, where enterprises engage in R\&D activity following intervals of reduced or a complete shutdown of R\&D operations. Much of this R\&D persistence and volatility can be observed through individual firm submissions to the national R\&D survey series, as firms continually indicate the start or temporary cessation of R\&D activity within a given reference period.

Understanding how the R\&D investment behavior and its resultant longitudinal patterns manifest within the South African business sector remains an important research opportunity emerging from this analysis. One element of this complex series of interrelated patterns determining $R \& D$ investment strategies manifests itself within the individual firm levels of $R \& D$ persistence and volatility over time.

The data demonstrates that a larger number of firms enter the South African R\&D statistics with a very low level of $R \& D$ investment and only perform $R \& D$ for two years or less. These firms usually invest less than ZAR 5 million annually and account for $48.5 \%$ of all R\&D performing firms within this ten-year reference period. This may mean that the individual firm may re-engage in $\mathrm{R} \& \mathrm{D}$ activities some years into the future or in relation to a different product, however, in terms of R\&D investment, the data series does tend to show interruptions that are more frequent within this level of R\&D investment.

As discussed in an earlier section, only $10.0 \%$ of firms within this analysis continually invested in $\mathrm{R} \& \mathrm{D}$ across a ten-year reference period. Investment in R\&D performance is highly concentrated in this smaller subset of R\&D performing firms in South Africa. Among the 1,437 firms, 144 (Table 5) were present in each survey year within this analysis. This smaller sub-set represents the most persistent $R \& D$ enterprises in South Africa. Among these 144 firms, 61 account for the largest contributions to BERD across the ten-year period. The 61 firms have had an average R\&D investment value exceeding ZAR 20 million for 10 or more consecutive years since 2006. This persistence of large BERD contributors is evident, with $42.0 \%$ of companies who invested ZAR 40 million or more per annum being consistently in the R\&D survey for 10 or more years (Table 7). This trend continues with a minimum of $25.0 \%$ of all large BERD contributors (greater than ZAR 5 million) similarly remaining active for nine or more consecutive years in the survey series.

Persistence in R\&D activity at firms across multiple consecutive measurement periods remains important as it ensures a stable and productive R\&D system and effective outflow of skills and knowledge. The data in Table 7 highlights the third major finding of this analysis, that firms committing BERD for an increased number of consecutive years tend to demonstrate larger annual investments over a longer periods compared to the majority of smaller BERD investments that generally span two years or less.

This trend is demonstrated in Table 7, wherein the 61 firms, investing more than ZAR 20 million in BERD for a period of 10 or more years contribute more to BERD than all firms investing any value of BERD for four or fewer years (1,044 enterprises). The BERD within the top two expenditure categories in the 10-year plus group (> ZAR 20 million) accounts for $87.0 \%$ of the total BERD investment for this highly persistent group of firms. Similarly, the 144 highly persistent firms (irrespective of BERD value) measured in the $R \& D$ survey for ten or more years account for $35.0 \%$ of total national GERD inputs.

The value and importance of this group of firms is significant and underlines the contribution that a holistic awareness of the importance of $R \& D$ persistence and volatility can illuminate over time.

The above analysis indicates that $30.0 \%$ of all BERD across the ten-year reference period is committed to R\&D from within a very small group of firms investing ZAR 20 million or more in annual R\&D activity.

In their 2017 paper, Kang et al. similarly note that firms investing in R\&D performance generally create greater "consistency over the long run and is more efficient than the same total investment over a shorter period" of time [Kang et al., 2017]. This trend is similarly visible in the South African R\&D survey data. Table 8 illustrates the influence of persistence and concentration on BERD over the ten-year reference period.

The above data illustrates how the natural attrition or volatility of firms entering and leaving the R\&D survey

Table 7. BERD Investment Group and the Persistence of Firms (\%)

\begin{tabular}{|c|c|c|c|c|c|c|c|c|c|c|c|}
\hline \multirow{2}{*}{$\begin{array}{l}\text { Expenditure group } \\
(Z A R \text { millions })\end{array}$} & \multicolumn{10}{|c|}{ Years in R\&D survey coverage } & \multirow{2}{*}{ Total } \\
\hline & 1 & 2 & 3 & 4 & 5 & 6 & 7 & 8 & 9 & 10 & \\
\hline More than 40 & 6.45 & 7.53 & 11.83 & 9.68 & 1.08 & 4.30 & 6.45 & 5.38 & 5.38 & 41.94 & 100 \\
\hline $20-40$ & 12.00 & 8.00 & 5.33 & 16.00 & 8.00 & 5.33 & 4.00 & 6.67 & 5.33 & 29.33 & 100 \\
\hline $10-20$ & 17.92 & 12.26 & 8.49 & 7.55 & 9.43 & 5.66 & 3.77 & 4.72 & 4.72 & 25.47 & 100 \\
\hline $5-10$ & 17.59 & 15.74 & 8.33 & 17.59 & 4.63 & 1.85 & 4.63 & 3.70 & 5.56 & 20.37 & 100 \\
\hline $1-5$ & 36.36 & 13.64 & 8.71 & 19.89 & 5.11 & 2.84 & 4.73 & 2.46 & 2.08 & 4.17 & 100 \\
\hline Less than 1 & 55.41 & 8.54 & 7.78 & 14.04 & 3.42 & 3.23 & 2.09 & 1.52 & 1.71 & 2.28 & 100 \\
\hline Total & 37.4 & 11.1 & 8.4 & 15.8 & 4.7 & 3.3 & 3.8 & 2.8 & 2.8 & 10.0 & 100 \\
\hline
\end{tabular}


Table 8. Concentration, Persistence and Volatility in BERD Investments

\begin{tabular}{|c|c|c|c|c|c|c|}
\hline $\begin{array}{l}\text { Expenditure group } \\
(Z A R \text { millions })\end{array}$ & $\begin{array}{l}\text { Year } 1 \\
\text { units }\end{array}$ & $\begin{array}{l}\text { Year } 10 \\
\text { units }\end{array}$ & $\begin{array}{c}\text { Unit change } \\
(\%)\end{array}$ & $\begin{array}{c}\text { Year } 1 \text { BERD } \\
(Z A R)\end{array}$ & $\begin{array}{c}\text { Year } 10 \text { BERD } \\
(Z A R)\end{array}$ & $\begin{array}{l}\text { BERD change } \\
(\%)\end{array}$ \\
\hline More than 40 & 53 & 29 & -45.3 & 6028129000.00 & 7088438834.00 & 17.6 \\
\hline $20-40$ & 51 & 25 & -51.0 & 1378556000.00 & 1845183319.80 & 33.8 \\
\hline $10-20$ & 49 & 23 & -53.1 & 711302000.00 & 1034283083.50 & 45.4 \\
\hline $5-10$ & 63 & 22 & -65.1 & 447218000.00 & 391577884.00 & -12.4 \\
\hline $1-5$ & 248 & 50 & -79.8 & 578502000.00 & 550327890.00 & -4.9 \\
\hline Less than 1 & 213 & 25 & -88.3 & 106454000.00 & 118264755.40 & 11.1 \\
\hline
\end{tabular}

shows an average loss of $60.0 \%$ across all BERD investments within the period. These losses are greatest within the smaller BERD investment groupings and appear $50.0 \%$ lower in the highest BERD grouping. Among the 213 enterprises that featured in the R\&D survey in Year 1, which committed less than ZAR 1 million in BERD, only 25 still reported ongoing R\&D in year 10 , indicating an attrition rate of $88.3 \%$. Converse to that, when studying the data for firms entering the survey in Year 1, committing ZAR 40 million or more in BERD, $55.0 \%$ of those units still appeared in the R\&D survey following Year 10. Similarly, when appraising financial investment in R\&D over the period, enterprises investing smaller amounts of BERD in Year 1 tend to show a reduction in $\mathrm{R} \& \mathrm{D}$ expenditure in Year 10.

However, similarly to the appraisal of unit count data, firms investing ZAR 10 million or more in Year 1 have generally demonstrated an increase in BERD commitment in Year 10 of between $17.0 \%$ and $45.0 \%$. The data in Table 8 further illustrates the fourth important finding from within this study that business enterprises that remain active in $\mathrm{R} \& \mathrm{D}$ for longer periods begin to invest increased $\mathrm{BERD}$ values and remain more persistent than enterprises committing less BERD for shorter periods (two years or less).

Given the results above and notwithstanding the fact that firms do not perform R\&D for the sake of it, there is still a need for instruments that can be used to incentivize firms to perform R\&D on a continual basis.

\section{Conclusion}

There are four key findings from the data. The South African business sector does not differ from that of developed countries in terms of persistence, concentration, and volatility of R\&D performance. Firstly, there is a large number of firms participating in the survey for one or two years and spending less than ZAR 1 million. Secondly, South Africa's business sector's R\&D performance is concentrated in a few firms that spend large amounts of money on R\&D performance. They are the largest contributors to BERD. South Africa's business sector R\&D investment is also concentrated within particular sectors of the economy. The two main ones are the financial intermediation, real es- tate, and business services sector and the manufacturing sector. Thirdly, firms that remain engaged in $R \& D$ performance for longer periods tend to invest more in $\mathrm{R} \& \mathrm{D}$ performance and remain more persistent than enterprises committing less for shorter times.

The large number of firms reporting R\&D expenditure of less than ZAR 1 million and participating in the survey for one year only should be further scrutinized as this study can only assume it is largely smaller firms making up the "tail" of BERD. Firms that spend more than ZAR 40 million drive R\&D spending in South Africa.

The policy question raised by these figures is how firms can be encouraged to increase their R\&D spending and continue such spending over an extended period in a way that supports other government policies such as those dealing with sustainable development and inclusion. Public support of private R\&D is usually through R\&D tax subsidies, direct government grants, contracts and other instruments. While government support of the business sector is desirable, it can have unintended consequences. There are different opinions regarding this. Rosenberg (1976) argues that policy makers should devote resources to those firms with a higher probability of continuing to perform $R \& D$ because the cumulative nature of the learning process may cause persistence [Rosenberg, 1976]. $\mathrm{He}$ further argues that the generation of knowledge is based on previous knowledge and affects future research. Other schools of thought suggest that the allocation of resources to high performers of $\mathrm{R} \& \mathrm{D}$ may lead to the exclusion of small firms and newcomers [Rammer, Schubert, 2016]. They also argue that allocation funds to persistent firms may be efficient because the expected output is maximized.

Persistence also boosts the probability of receiving funding if a firm has a proven record of successful performance over the years. However, the allocation of funds to known performers may also lead to dependence on a small amount of industries. Other approaches to funding which have been used in a number of countries is the voucher scheme [OECD, 2010] which allows a small firm to apply for a voucher which can be used to pay for assistance from a university, polytechnic, or government research organization. 
The empirical findings from this study have raised questions about the appropriate policies for persistent large $\mathrm{R} \& \mathrm{D}$ performers, smaller $\mathrm{R} \& \mathrm{D}$ performers, and firms that spend little time performing R\&D. The firms, especially large performers, include the state-owned enterprises (SOEs) which require a different policy approach from that for private firms. Similarly, any policy intervention may lead to either the intended outcome or may have negative impact that affects the R\&D performance of firms.
Finally, an understanding of the concentration of business R\&D may assist in distinguishing other policies such as innovation policy from R\&D and S\&T policies.

The authors wish to acknowledge Professor Fred Gault for his invaluable and unwavering support on the production of this manuscript. The authors also acknowledge Mr Sibusiso Siqubu for his help in availing the data, Ms Natalie Vlotman in proofreading parts of the document and checking the data, figures, and tables.

\section{References}

Antonelli C., Crespi F., Scellato G. (2013) Internal and external factors in innovation persistence. Economics of Innovation and New Technology, vol. 22, no 3, pp. 256-280.

Average Salary Survey (2019) South Africa - 2018/19. Available at: https://www.averagesalarysurvey.com/south-africa, accessed 22.06.2019.

Berry A., von Blottnitz M., Cassim R., Kesper A., Rajaratnam B., Ernst van Seventer D. (2002) TIPS - The Economics Of SMMES In South Africa. Available at: http://www.tips.org.za/research-archive/trade-and-industry/item/204-the-economics-of-smmes-in-south-africa, accessed 12.05.2019.

Cohen W.M., Levinthal D.A. (2006) Absorptive Capacity: A New Perspective on Learning and Innovation. Administrative Science Quarterly, vol. 35, no 1, pp. 128-152.

Government of Canada (2019) SRe ED Tax Incentives. Available at: https://www.canada.ca/en/revenue-agency/services/scientific-researchexperimental-development-tax-incentive-program/claim-sred-tax-incentive-what-tax-incentive.html, accessed 27.05.2019.

HSRC (2017) South African National Survey of Research and Experimental Development: Main Report 2016/17, Pretoria: Human Sciences Research Council.

Kang T., Baek C., Lee J.-D. (2017) The persistency and volatility of the firm R\&D investment. Research Policy, vol. 46, no 9, pp. $1570-1579$.

Máñez J., Rochina-Barrachina M, Sanchis-Llopis A., Sanchis-Llopis J. (2009) The role of sunk costs in the decision to invest in R\&D. Journal of Industrial Economics, vol. 57, no 4, pp. 712-735.

Máñez J., Rochina-Barrachina M., Sanchis-Llopis A., Sanchis-Llopis J. (2010) The Role of Learning in Firm R\&D Persistence (FUNCAS Working Paper 500), Madrid: FUNCAS.

NRC (2019) About the NRC Industrial Research Assistance Program. Available at: https://nrc.canada.ca/en/support-technology-innovation/ about-nrc-industrial-research-assistance-program, accessed 22.06.2019.

OECD (2010) Innovation Vouchers, Paris: OECD. Available at: https://www.oecd.org/innovation/policyplatform/48135973.pdf, accessed 19.05.2019.

OECD (2015) Frascati Manual 2015. Guidelines for Collecting and Reporting Data on Research and Experimental Development, Paris: OECD.

OECD (2017) OECD Science, Technology and Industry Scoreboard 2017, Paris: OECD. Available at: https://www.oecd-ilibrary.org/scienceand-technology/oecd-science-technology-and-industry-scoreboard-2017_9789264268821-en, accessed 22.06.2019.

OECD (2019) OECD Main Science and Technology Indicators 2018, Paris: OECD.

Rammer C., Schubert T. (2016) Concentration on the Few? R\&D and Innovation in German Firms 2001 to 2013 (ZEW Discussion Paper No. 16-005), Karlsruhe: Centre for Economic European Research. Available at: http://ftp.zew.de/pub/zew-docs/dp/dp16005.pdf, accessed 13.03.2019.

Rosa J.M., Mohnen P. (2013) Doing Re D in a Closed or Open Mode: Dynamics and Impacts on Productivity (MERIT Working Paper 060), Maastricht: United Nations University - Maastricht Economic and Social Research Institute on Innovation and Technology (MERIT).

Rosenberg N. (1976) On Technological Expectations. The Economic Journal, no 86(343), pp. 523-535.

Rumbelow J., Blankley W. (2012) Concentration, persistence and volatility of R\&D performing businesses in South Africa from $2001 / 02$ to 2008 /09 with implications for measurement excellence and policy impact. Paper presented at the MEIDE (Micro Evidence on Innovation and Development) Conference, 21-23 November 2012, Cape Town, South Africa.

Schellings R., Gault F. (2002) Size and Persistence of R\&D Performance in Canadian Firms 1994 to 2002 (Catalogue 88F0006XIE, no 008), Ottawa: Statistics Canad 